\title{
VISION ON BIODIVERSITY: ECOTOURISM AND BIODIVERSITY CONSERVATION IN BANGLADESH
}

\author{
Bashar, M. A. \\ Environmental Biology and Biodiversity Laboratory (EBBL), Department of Zoology, University of \\ Dhaka, Dhaka-1000, Bangladesh
}

In the observation of World Environment Day, the theme chosen for the year, 2016 was 'Connecting People to Nature'; for the year of 2017, it was 'Biodiversity and Sustainable Tourism'; and in this year 2018, it is 'Celebrating 25 Years of Action for Biodiversity'. The biodiversity concerning organizations have agreed in a statement that the importance of biodiversity may be focused through the application of various frontiers of the biodiversity. The organizations realize that it is necessary to analyze how the ecotourism justifies its role to bring the people near to nature in an ecosystem of the biosphere. In the socio-ecological aspects, the ecotourism stands as one of the supportive frontiers of biodiversity for utilization of the bio-ecological resources of an area of the planet. The present paper deals with the matters in a collective and integrative structure.

\section{What is ecotourism?}

Ecotourism is the blend of two words "ecology" and "tourism". Many definitions of "ecotourism" have been emerged since the term was coined in 1987. In 1991, The Ecotourism Society (TES) defined ecotourism as: "Ecotourism is a responsible travel to natural areas that covers the environment and sustains the well being of local people" (Wood 1996). Expanding on this definition, TES has developed the following seven basic principles of ecotourism.

* It avoids negative impacts that can damage or destroy the integrity or character of the natural or cultural environments being visited.

* It educates the traveler on the importance of conservation.

* It directs revenues to the conservation of natural areas and the management of protected areas.

* It brings economic benefits to local communities and directs revenues to local people living adjacent to protected areas.

* It emphasizes the need for planning and sustainable growth of the tourism industry and seeks to ensure that tourism development does not exceed the social and environmental "capacity".

* It retains a high percentage of revenues in the host country by stressing the use of locally-owned facilities and services.

* It performs eco-environmental events for conserving environmental soundness by facilitating anthropogenic activities of the nature lovers.

Ecotourism covers the scope of tourism that draws upon natural, human-made and cultural environments. It describes any theme of travel to experience natural environments or settings. However, the ecotourism society further add social responsibilities to the definition of ecotourism and states it as "purposeful travel to the natural areas that creates an understanding of cultural and natural history of the environment, safeguarding the integrity of the ecosystem while producing economic opportunities that make the conservation of natural resources beneficial to local people".

Ecotourism often combines elements of scientific investigation, education, recreation and adventure. However, it is very difficult to describe ecotourism, particularly with the diversity, combinations and 
degrees of orientations and interests involved. According to Laarman (1987) and Durst (1994), ecotourism has two dimensions like hard and soft, with the first distinction being whether or not the interest of the people in natural history is dedicated or causal. The theme initiates that the human society needs to bring people to the nature for their own comfortability and survivals. Nature allocates people by offering them various necessities in human life; and by showing eternal benefits to the people for their eternal pleasure. Ecotourism is one of the tools that could be used by the humans to enjoy the eternal necessities in life and the benefits. Dedicated ecotourism and natural history travel is practiced by ornithologists, botanists and other professionals, as well as, by people with serious interests in natural history areas. This can be considered "hard core" natural history travel. On the other hand, "soft" ecotourism, or natural history tourism, combines nature-oriented travel with beaches, deep-sea fishing, shopping, culture, etc. Tourism and trips in this category tend to try and combine a variety of motivations and activities in single trip, e.g. viewing tropical forest scenery, watching birds and wildlife, visiting archeological ruins etc. The second hard-soft distinction refers to the physical rigor of the experience. Will the visitors have to walk miles into undeveloped wilderness, sleep in a tent or crude shelter and to tolerate primitive sanitary conditions? Or will the visitor stay in quality accommodations, eat in good restaurants and be conveyed in comfortable transport? Some of hard tourism, from the standpoint of dedication to natural history, falls into the soft category of physical rigor. The inverse also occur when causal devotees seek (or unwillingly endure) rigorous travel experiences. There are some varying degrees and overlapping of both hard and soft ecotourism in orientations and combinations. Both types may incorporate some ecological aspects and techniques. With the ecological and environmental interests today, ecological themes and aspects are growing more and more popular in tourism.

\section{Ecotourism is a conservation tool}

Most definitions of ecotourism mean a special form of tourism that meets three criteria like:

1. It provides conservation measures.

2. It includes meaningful community participation; and

3. It is profitable and can sustain itself.

Ecotourism makes a model to conserve nature and natural resources. The resources create economic supports and enhance social strengths. The supports provide encouragement to accelerate conservation of resources and also the environment. Such environment maximizes resource-growing of an ecosystem. Resource management is the part of nature conservation.

Environmental tourism is grounded in the concept of the sustainable use of natural resources (Kusler et al. 1990). Ecotourism evolved in the last four decades from the interaction of environment and tourism interests. Ecotourism should be based upon a relatively undisturbed natural environment, be non-degrading and non-damaging, be subject to adequate management and continue directly to the continued protection and management of the protected area used. Ecotourism places many demands on a wilderness area, foremost being the ability to accommodate tourists while still providing the experiences. The advantage for the wilderness area is that "because ecotourism is primarily resourcebased, protection of these natural and archaeological resources is essential for sustained ecotourism" (Kusler 1990). Many conservation organizations and governments see ecotourism as the means to both preserve and develop remote areas.

Ecotourism, or nature tourism, is just one component of the tourism industry. A precise definition of tourism is exclusive because of its complex nature, involving a combination of attractions, transport, accommodation, supporting facilities and infrastructure. It is generally defined by its spatial dimension and is thus often characterized by criteria such as a minimum distance of travel or travel involving at 
least a one-night stay away from home. The lack of a common definition results in multiple interpretations, nevertheless ecotourism should support the concepts and principles that contribute to integrating social, economic and environmental goals. Therefore, ecotourism should have based on the following points:

* To attract tourists to natural environments which are unique and accessible.

* To be used to improve nature conservation through education.

* To lead to changing of attitudes in local people and government.

* To provide employment and entrepreneurial opportunities to local people.

* To generate revenue.

On sustainable and long-term basis of the macro level, ecotourism can generate economic returns that supersede the potential revenue to the national treasury that is "lost" by foregoing timber harvesting or other exploitive uses on a short term basis. In Costa Rica, an organization of American States' study reported in 1987 that even 10 years ago, a single national park, Corcovado, generated over US\$ 1 million a year in foreign earnings. Prior to the recent social and political strife in Central Africa, over 6,000 people visited Rwanda's Park National Des Volcans each year, generating over a million dollars in much needed foreign currency through park entry and gorilla watching fees. It has also resulted in the government of Rwanda stopping the exploitation of gorilla habitat from the park to donate native farmers, while the presence of tourists apparently drove off poachers who were making serious inroads in the gorilla population.

Ecotourism in developing countries with tropical forests has become big business. The growing demands for ecotourism present numerous opportunities for increasing sustainable, rural and national development, while still protecting tropical forests and their biodiversity. On the other hand, the present deforestation and degradation patterns for tropical forests in Asia and other countries of the South may well remove these opportunities in the very near future.

\section{Mechanization for biodiversity conservation}

It is told that ecotourism is able to increase revenue in more sound and pleasure way than any other sources of revenue generation. The mechanization of using ecotourism as a tool is the strategic adoption of ecotourism investment in the communities.

The World Travel and Tourism Council (WTTC) has identified six major reasons for ecotourism investment in local communities. These are:

First. According to the WTTC, tourism is the largest industry in the world. "The travel and tourism industry employs 127 million workers throughout the world (one in fifteen workers worldwide). Ecotourism is the largest growing sector of the tourism industry, with (1994 surveys showing) 40-60\% of all international tourists (528.4 million) are nature tourists (211-317 million, contributing an international direct economic impact of US\$166-250 billion) and that 20-40\% are wildlife-related tourists (106-211 million, contributing an international direct economic impact of US\$83-166 billion)". Tour operators, developers and governments obviously see future money to be made.

Second. Increasing human populations and their demand on natural resources make it almost impossible for developing countries to leave large areas undeveloped. It is this necessity for development of natural areas to produce economic benefits that makes ecotourism so attractive. "[Environmentalists and...officials in Madagascar] are counting on the burgeoning worldwide interest in 'ecotourism' to help to save what's left of the country's natural resources. They are hoping better roads and hotels will increase tourism enough to produce profits to save the island's remaining rainforests" (Hale 1989). 
Third. The world's biodiversity is being lost at an estimated 140 species per day. It is imperative that biosphere reserves are established in many tropical countries — the "hot spots" of biodiversity —in order to protect what is left. Ecotourism is an attractive use of these reserves, as it aims to protect natural resources, not destroy them. Ecotourism also brings in foreign exchange that helps to support the maintenance of these reserves.

Fourth. In many countries these reserves are created from lands belonging to the government. The government has the right to sell that land to foreign producers, to logging companies, or to create a reserve with it. Local people living in these areas many have no right to ownership of the land. Even when indigenous communities have been living there for generations, many times the land area was not titled to them and therefore belongs to the government. However, in order to sustain a reserve and its ecotourism, government, developers and scientists must invest in these communities and recognize the rights of local people, who have protected these natural resources for so long.

Fifth. Local communities must be involved from the very beginning in planning a reserve and be able to give their opinions and to be heard. Ecotourism can bring many changes to a society and these communities must have a say in what they are willing to accept. Some of these changes can be very culturally detrimental. Without the whole-hearted support of these local communities, ecotourism and the reserve can fail, locals may actually start killing wildlife and destroying forests in retribution (Hughes 1996, Tchamie 1994, Stonich 1996,).

Sixth. With money from ecotourism, jobs for local people become available (including ownership and management jobs) and health and education of local people can be improved. With education of women and decreased mortality rates for infants, women have less number of babies and start giving birth later in life. These health and education improvements can go a long way in alleviating poverty, population growth and land-distribution problems, which are the main causes of natural resource degradation and biodiversity loss (Murdoch 1980).

Humans are part of the ecosystems that ecotourism seeks to protect. Ecotourism is not only a means for visitors, governments and scientists to conserve protected areas, but also recognizes that local communities are stakeholders in the ecotourism process and its success or failure. The main point to this argument is the debate over whether humans are part of ecosystems or not and whether their inherent rights to the land should be considered. If governments of developing countries are aiming to lower population growth and improve standards of living, they will invest in local communities through ecotourism. If governments are aiming to maximize profits with foreign currency, then human rights are not a priority and they will not invest in local communities. Much of this depends on the stability of governments and whether they are in for the long-term or the short-term (Pleumarom 1997).

The following is a quote from a group of local people representing their own tourism organization, ATEC, from the Talamanca region of Costa Rica, presenting a talk at an ecotourism conference:

"ATEC would like to encourage the ecotourism establishment to reflect on why the opportunity for international ecotourism exists. Is it not because traditional societies in fragile natural environments throughout the world learned, through centuries of experience, how to live within ecological constraints and passed this knowledge on through centuries and passed this knowledge on through myth and ritual and practice?"

"Just as Columbus "discovered" America 500 years ago, the ecotourism establishment is out "discovering" ecotourism sites in the underdeveloped countries. We who live in such settings hope that the ecotourism industry will take care to avoid repeating Columbus's crimes against indigenous people who have for centuries been the caretakers of the forests."

"We are not waiting for you to come 'develop' us. History has taught us to be cautious about your schemes. We are hoping that when you come to our communities you will come humbly, wanting to 
learn from us what we can teach you about environmentally responsible living. We hope you will help us to create opportunities to share our knowledge and the richness of our natural resources with you in ways that recognize and reinforce the dignity and autonomy of our people" (Salazar et al. 1991).

\section{Bangladesh scenario}

In Bangladesh, we have some important forest areas such as Sitakundo, Karaerhat and Chunati in Chittagong district; Eidgaon, Eidgar and Fashiakhali in Cox's Bazar district; Lawasara and Rama Kalenga in Sylhet; Sherpur in Mymensingh; Modhupur in Tangail; Nijhum islands in Noakhali and the Sundarbans the largest mangrove in Khulna to be acted as the ecotourism spots and could be used as the potential sources of tools for the conservation of forests, nature and the beauties of the nation's endemism. Of them, the Sundarbans could be taken as an example. The Sundarbans, a cluster of islands with an approximate area of 3,600 square kilometers, is the greatest mangrove forest in the world. It is located at the southern extremity of the Ganges delta bordering the Bay of Bengal in the southwest of Bangladesh, in the district of greater Khulna. Non-wood forest products (NWFPs) provide employment to about 299,000 people in Bangladesh. Much of this employment continues throughout the year, or at least during the agricultural off-season. NWFPs from mangrove forests contribute an estimated of Taka 717 million (US\$ 17.9 million) annually to the Bangladesh economy, directly or indirectly. For our most of the mangrove NWFPs, there are no policies, rules or regulation applicable to their growth and harvesting. Processing of most NWFPs in the mangroves is still primitive. Product quality is low and, therefore, less accepted in the international markets.

Miles after miles, the lofty treetops of the Sundarbans form an unbroken canopy, while nearer the ground, the effects of high and ebb tides are marked on the soil and tree trunks. The variety of the natural mangrove has much to offer an inquisitive visitor. Land and water meet in many novel ways. The Sundarbans is the natural habitat of the world-famous Bengal tiger, spotted deer, crocodile, jungle fowl, wild boar, lizards, Rhesus monkeys and an innumerable variety of beautiful birds. Though the beauty of butterfly-colonization and their artistic conservation techniques could not draw the attention of any researcher and author so far working on the fauna of the Sundarbans. It is the most unfortunate situation in the field of the research regarding the Sundarbans still today. For the botanist, the nature lover, the poet and the painter, this land provides a variety of wonders. Thousands of meandering streams, creeks, rivers and estuaries add charm. The many sail boats loaded with timber, golpatta (Nipa fruticans), fuel-wood, honey, shells, and fish add to the serene natural beauty of the Sundarbans. The main attractions of this area for tourists include wildlife photography, viewing and studying the world's largest mangrove forest, boating, and meeting local fishermen, wood-cutters and honey collectors. Also of great importance are the peace and tranquility of the wilderness. In the Chandpai region it is fascinating to see the nomadic fishermen (living with their families on boats) catching fish with the help of trained otters. Exciting activities take place in Dublar Char (Small islands in the Sundarbans) in the forest where fishermen from Chittagong gather for four months (mid-October to February) to catch and dry fish. But, the most daring and exciting of all activities involve the honey collectors who work in groups for just two months (April and May). It is interesting to see how they locate a hive and collect the honey. Famous spots include Hiron Point (Nilkamal) for observing tiger, deer, monkey, crocodiles, birds and natural beauty. Katka is another spot for deer, tiger, crocodiles, variety of birds and monkeys, and a morning and evening symphony of wild fowls. The vast grassy meadows running from Katka to Kachikhali (Tiger Point) provide opportunities for wild tracking. Tin kona Island has tiger and deer. Dublar Char Island is interesting for its fishermen and its herds of spotted deer. The similar history of beauties, activities, sceneries, life styles, livelihoods, cultures and involvement strategies in the forest 
conservation of the local people of different forests in Bangladesh could be cited also in the respect, but it is avoided here in the present text.

Ecotourism models around the world differ in their biases. In Bangladesh, it is necessary to follow a model that incorporates local communities' involvement; members of the local communities are usually landowners. It is necessary for Bangladesh to recognize that ecotourism has the potential not only to provide quality employment income and business opportunities for local people, but also to act as a catalyst for the preservation of the natural environment and indigenous/tribal cultures. Bangladesh is the delta of Himalayas; the entire country is natural laboratory for research works in the field of nature conservation. The country is bordered within 54 thousand square miles of the north of the Bay of Bengal. In mountains and in the plain lands more than 80 percent of the population reside, comprise 70 percent of total land area. About 85 percent of the total population lives in rural areas, but migration to urban areas is significant and increasing. Bangladesh's natural heritage and the present situation have two words appropriate for biodiversity "characteristics": species richness and small population size in the species.

In Bangladesh, biodiversity is running under 'double sided' characters. This is the characteristic of Bangladesh biodiversity in the present time, but there could be a change in the character very soon. One side of the character is the 'species richness'. It means that still number of species is very high in Bangladesh forests and in aquatic ecosystems. Another side is that, the population size of the existing species is very low almost in all the cases. The double sided characteristics bear hopefulness in the way that if the 'species richness' could be preserved starting from just now, then the biodiversity could be raised up to the state to be used as economic sources. On the other hand, low population size at the species always risks bringing the species for the extinction. So, in Bangladesh majority of the species are remaining at the stage of seriously "threatened" status. This is the negative side of the double sided characteristics. It is now realized that an all-out species conservation strategies must be undertaken immediately without getting any delay. Otherwise, species richness will fall suddenly and as a consequence both forest and aquatic ecosystems in the country will have negative impact on the biodiversity as a whole. Positive side of the double sided characteristic is that, if we can go quick for conserving species and their population size, still there is high possibility of keeping the ecosystems 'rich in biodiversity'. Then, definitely the value of biodiversity could be utilized for the benefit of the nation.

Bangladesh's vegetation and wildlife have exceptional scientific and genetic interests due to the high proportion of endemic species. Its biodiversity is threatened due to a shift from subsistence to a cash economy and increasing population. Deforestation caused by cash-crop development, urbanization and small holder farming, is currently at high percentage per annum. One example could be given from Modhupur sal forest in picture (Occupation of sal forest by cultivation of banana for commercial purpose). The threat of Bangladesh biodiversity is serious, but not yet irreparable. As development and agriculture accelerate, however, damage may soon be irreparable unless sustainable development is established at grass root levels. Development within the industry of ecotourism and its marketing has given insufficient attention to the possible significance of Bangladesh's cultural and natural heritage. Places of historic importance, ancient archeological sites, Bangladesh rainforests, mangrove forests and coral reef ecosystems have been underutilized as tourist attraction. The concept of sustainable tourism, however, can find its greatest support through the increased development of ecotourism. Now, is the perfect time to pursue sustainable tourism, as Bangladesh is moving towards a range of new initiatives in the area of sustainable resource use under its national environmental strategies. All could be made possible and accessible if proper researches are envisaged and practiced at the executive levels and dealt with honesty and sincerity with the patriotic connaissance or intuitive knowledge. 
Bashar et al. (2015) made an experiment on wildlife conservation through butterfly colonization. They have successfully shown that establishment of butterfly open colonization can create an ecologically 'furnished' open site where species richness becomes enriched. This fact may be used in promoting ecotourism. It is found that the establishment of Butterfly Park can encourage ecotourism and hence can contribute to national economy.

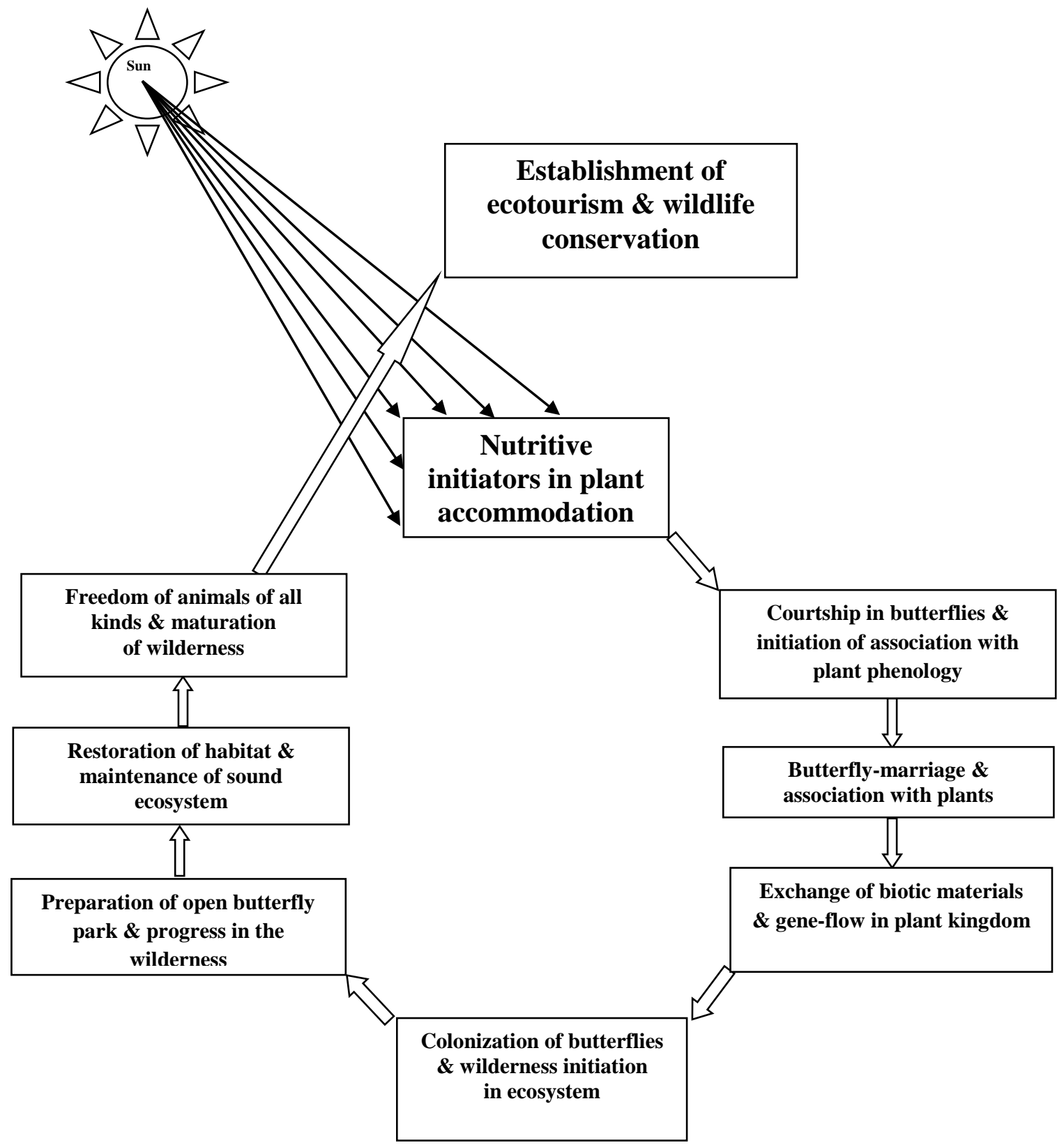

Fig. 1. Butterfly colonization and successiveness in establishment of wildlife conservation habitat.

The author depicted clearly that, in a butterfly park one can observe the wonderful maneuvering of adult butterflies. Flight adaptation is the most notable and interesting function of the adult butterflies. Much smaller muscles located directly on the base of wings control the direction and angle of wings during flight. The observers may notice that there are variable flight characteristics in different butterfly species. The synchronization of stages of the two biotic factors (Plant-Insect) can present the real beauty 
of nature in a flowering area when colonization of butterflies could be made in a scientific model for the ecotouristic approaches. Moreover, a butterfly park does not only attract tourists as the nature lovers. But the local people of adjoining areas can also utilize these facilities as a source of income and can participate in the conservation of biodiversity plus plant-animal association. So, Butterfly Park (Butterfly Colonization) could be an alternate source of income contributing to poverty alleviation by employers. Hence the national economy might be flourished by exporting nontraditional items made from butterflies as practiced by many countries of the world. Moreover, the interaction between the butterfly-activities and the phenological stages of the plants stand as key tools in nature for speciation both in flora and fauna in the wild state (Scriber 1990, Scriber et al. 1990, Bashar et al. 2015).

\section{Butterfly colonization and biodiversity conservation model}

Establishment of ecotourism model and its sustainability may be illustrated by a schematic diagram with scientific events of butterfly colonization (Fig. 1). Interaction between butterfly and associated plants is a vital tool for conservation of biodiversity as a whole. And this is a dynamic mechanism existing in nature, we are to discover and use it practically for conservation of biodiversity. Bashar et al. (2015) made a thorough study on the aspect of plants-insects combination and their assemblages through colonization of butterflies and establishment of Butterfly Park. These two biotic aspects (ButterflyPlants) play profound role for multiplication and existence of floral and faunal population size in an experimental area. They examined to discover how this role occurs in nature. It is evidenced that butterflies carry gene-flow activities for plants (especially in the forest) freely and cause the pollination of the related plants; and then the plant population increases normally. On the other hand, plants provide essential nutritional materials to butterflies for their larval development, adult activities, survivals and for their shelters. But how this happens in nature and how this could be used as vital tool for using conservation of biodiversity? The results of the research programme are dealt with questions. Estimation of wildlife population with seasonal variations has been made by using population census formula and population fluctuation database.

\section{Wildlife conservation and the butterfly colonization}

Plantation initiation in the Butterfly Colonization Centre (BCC) at the Bhawal National Park was initiated in the year 2004 (Bashar 2015). The author and his research team started the colonization of butterflies after accommodating the plants in the centre which were related to the butterflies for providing nutrition, egg-laying supports, shelters and all other abiotic/climatic requirements. They recorded the gradual assemblage of the wild vertebrates in the BCC from the year 2007, when all colonizing requirements for the butterflies were made sustainable in the centre. The experiments included data up to the year 2014 (Fig. 2). Regular records were maintained on the wild vertebrate populations and their concomitant increase from the year 2007 and it was estimated in four groups, such as amphibians, reptiles, birds and mammals. The vertebrate species record was maintained in the BCC during the study period are stated below.

Amphibians: Available amphibians in the BCC are Hoplobatrachus tigerinus, Duttaphrynus melanosfictus, Kaloula pulchra, Ichthyophis glutinosus, Fejervarya limnocharis, Microhyla berdmorei, Microhyla rubra, Sylvirana leptoglossa, and Polypedates maculates. In 2011, the size of population was $47 \pm 5$ and it stood $158 \pm 12$ in 2014 .

Reptiles: Reptiles inhabited in the BCC are Varanus bengalensis, Ptyas mucosa, Xenochrophis piscator, Calotes versicolor, Gecko gecko, Typhlops diardii, Scincella reevessii, Mabuya carinata, Naja naja, Lycodon aulicus, and Dendrelaphis tristis. The size of reptilian population was $122 \pm 9$ in 2011 and it increased up to $277 \pm 13$ in 2014. 
Birds: The available birds in the BCC are Eudynamys scolopaceus, Hierococcyx varius, Centropus sinensis, Streptopus chinensis, Corvus macrorhyncho, Dicrurus macrocercus, Copsychus saularis, Acridotheres tristis, Sturnus malabaricus, Sturnus contra, Orthotomus sutorius, Turdoides straitus, Pycnonotus cafer, Passer domesticus, Halcyon smyrnensis, Merops orientalis, Athene brama, Psittacula krameri, Cuculus micropterus, Cebtrapus bengalensis, Copsychus malabaricus, and Milvus migrans. In 2011, the size of population was 970 \pm 21 and it stood 2333 \pm 21 in 2014.

Mammals: The mammals found in the BCC are Suncus murinus, Pteropus gigenteus, Macaca mulatta, Herpestes edwardsi, Manis crassicaudata, Bandicota bengalensis, Callosciurus pygerythrus, Vandeleuria oleracea, Felis viverrina, Herpestes auropunctatus and Canis aureus. The mammalian population was 194 \pm 11 in 2011 and it increased up to $372 \pm 9$ in 2014.

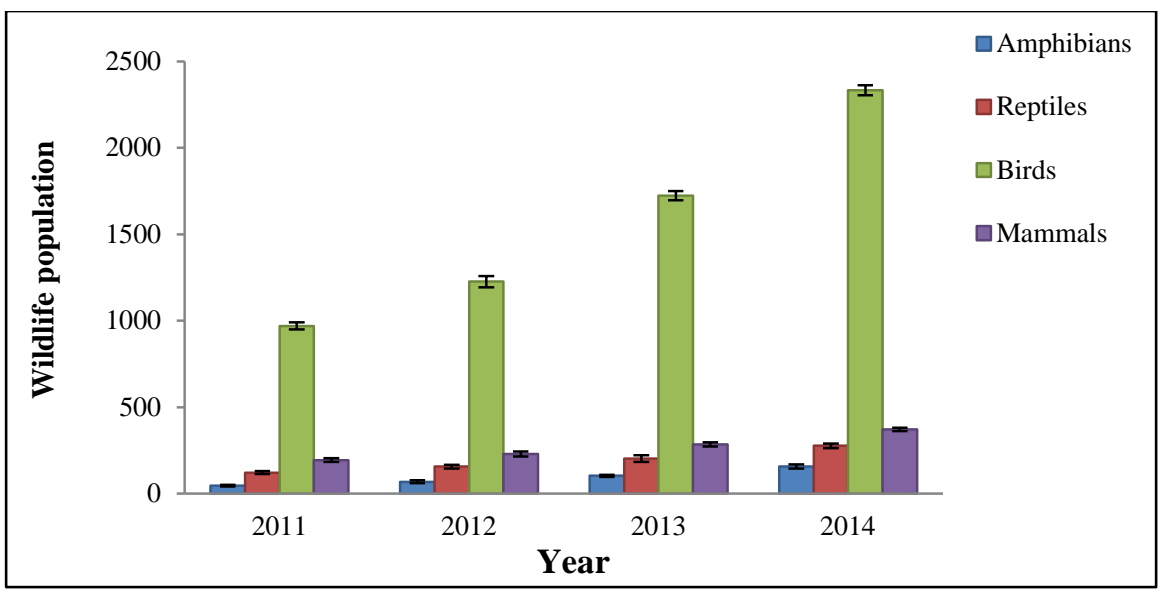

Fig. 2. Concomitant increase of wild vertebrates with the progressive success of the butterfly colonizing mechanism in the butterfly colonization centre (BCC) for the duration of 2011-2014 (after: Bashar et al. 2015).

The author observed the concomitant increase of wild vertebrates with the progressive success of the butterfly colonizing mechanism in the BCC from 2011 to 2014. It is evident that the insect interaction with plants (especially the phytophagous pollinating insects and the flowering plants with entomophilous pollens) establishes strong gene-flow mechanism in the forest ecosystem. Then the forest ecosystem became healthy and it provided more functional services both to the plants and animals maintained there. Consequently, the ecosystem became suitable and compact home for the successive trophic levels which maintained fruitful services and favourable habitats to all the wild animals living in the ecosystem. The fact remains that the forest can serve as a home of "in-situ" conservation site for wildlife fauna (Bashar 2011).

It is delightful to mention that Biodiversity Day 2018 was celebrated with the theme 'Celebrating 25 Years of Action for Biodiversity' on 22 May, 2018. The theme was inaugurated with a vow not only in recognizing and concerning past activities to protect and conserve biodiversity, but also this event will be inspirational for future generations. The celebration would be more worthy while ensuring people's participation directed to encourage as well as to involve them in understanding and realizing the significance and values of biodiversity. Ecotourism might be suggested as a tool to connect people to nature more naturally through celebrating 'Silver Jubilee' of dynamicity/functionality in actions, approaches and measures already taken and to be taken towards sustainable conservation of biodiversity and bioresources. Let us celebrate the day regularly! 


\section{REFERENCES}

Bashar, M. A. 2011. Honey collection and biodiversity loss in mangrove ecosystem. The Daily Independent (Science \& Technology). June 17, 2011.

Bashar, M. A., H. R. Khan, S. Rahman, Eftesum, K. Chowdhury, M. M. Alam and G. Maula. 2015. Wildlife conservation through butterfly colonization. J. biodivers. conserv. bioresour. manag. 1(1): 71-82.

Durst, P. 1994. Planning for ecotourism within the frame work of the tropical forests action programme. Forest Nears. XXI: 7-14.

Hale, E. 1989. Planet in Peril: Tourism may save island's resources. Florida Today.

Hughes, D. M. 1996. When parks encroach upon people: Expanding National Parks in the Rusitu valley, Zimbabwe. Cultural Survival Quarterly. 20(1): 36-40.

Kusler, J. A. 1990. Ecotourism and resource conservation: Introduction to issues. The Second International Symposium on Ecotourism and Resource Conservation. Florida, USA. 885 pp.

Kusler, J. A. and M. E. Kentula (eds.). 1990. Wetland Creation and Restoration: The Status of the Science. Island Press, Washington DC, USA. 468 pp.

Laarman, J. G. 1987. Nature-Oriented Tourism in Costa Rica and Ecuador: Diagnosis of Research Needs and Project Opportunities. Southeast Center for Forest Economics Research, Research Triangle Park, North Carolina, USA. FPEI working paper No. 6. 18 pp.

Murdoch, W. W. 1980. The poverty of nations: The political economy of Hunger and Population. The John Hopkins University Press, Baltimore, Maryland. 367 pp.

Pleumarom, A. 1997. Open questions concerning the concept, policies and practices of Ecotourism. In: J. Bornemeier, M. Victor and P.B. Durst (eds.). Ecotourism for forest conservation and community development. RAP Publication, Bangkok, Thailand. $281 \mathrm{pp}$.

Salazar, M., P. Palmer, W. Barthel and J. Reed. 1991. Local participation in ecotourism development, Talamanca, Costa Rica: Opportunities and Obstacles. International Second Symposium on Ecotourism \& Resource Conservation. Miami, Florida, pp. 371-381.

Scriber, J. H. 1990. Interaction of introgression from Papilio glaucus canadensis and dispause in producing "spring form" of eastern tiger swallowtail butterflies, P. glaucus (Lepidoptera: Papilionidae). Great Lakes Entomol. 23: 127-138.

Scriber, J. H., M. H. Evans and R. C. Lederhouse. 1990. Hybridization of the Mexican swallowtail Papilio alexiarcs gracia (Lepidoptera: Papilionidae) with other glaucus group species and survival of pure and hybrid larvae on potential host plants. J. Res. Lepid. 27: 222-232.

Stonich, S. C. 1996. Reclaiming the Commons: Grassroots Resistance and Retaliation in Honduras. Cultural Survival Quarterly. 20(1): 31-35.

Tchamie, T. T. K. 1994. Learning from Local Hostility to Protected Areas in Togo. Unasylva. 176(45): $1-8$.

Wood, M. E. 1996. The evolution of ecotourism as a sustainable development tool. The sixth International Symposium on Society and Natural Resource Management. Pennsylvania State University, 18-23 May.

DOI: http://dx.doi.org/10.3329/jbcbm.v4i1.37871 